\title{
Reconsidering the origin of the Sedrun fans (Graubünden, Switzerland)
}

\author{
Catharina Dieleman ${ }^{1}$, Susan Ivy-Ochs ${ }^{2}$, Kristina Hippe ${ }^{2}$, Olivia Kronig ${ }^{2}$, Florian Kober ${ }^{3}$, and Marcus Christl ${ }^{2}$ \\ ${ }^{1}$ Institute of Geology, ETH Zurich, 8093 Zurich, Switzerland \\ ${ }^{2}$ Laboratory of Ion Beam Physics, ETH Zurich, 8092 Zurich, Switzerland \\ ${ }^{3}$ NAGRA, Hardstrasse 73, 5430 Wettingen, Switzerland
}

Correspondence: $\quad$ Susan Ivy-Ochs (ivy@ phys.ethz.ch)

Relevant dates: $\quad$ Published: 20 April 2018

How to cite: $\quad$ Dieleman, C., Ivy-Ochs, S., Hippe, K., Kronig, O., Kober, F., and Christl, M.: Reconsidering the origin of the Sedrun fans (Graubünden, Switzerland), E\&G Quaternary Sci. J., 67, 17-23, https://doi.org/10.5194/egqsj-67-17-2018, 2018.

\section{Introduction}

Four alluvial fans, Pulanera, L'Ondadusa, Drun and Bugnei, located near the town of Sedrun in the upper Vorderrhein Valley (Fig. 1), are striking in that they have a common aggradation surface $\left(\sim 1^{\circ}\right.$ slope oriented along the main valley axis) and distinct coterminous cut-off toes. Similar coalesced fans with marked incised toes occur just downstream at Disentis (Fig. 2a). These geomorphological characteristics suggest that the fans built up for a limited period of time and then were abruptly incised by the Vorderrhein River. Switching between aggradation, fan abandonment and channel entrenchment can be a response to (1) variation in discharge due to climate changes or extreme precipitation events, (2) decreases in sediment supply reflecting waning (e.g. paraglacial) sediment availability, (3) tectonic uplift, or (4) changes in base level (Harvey et al., 2005; Hornung et al., 2010, and references therein). Inside a mountain range, change in local base level can be caused by large-scale downstream blockage by a glacier, a landslide or a man-made dam (Korup and Tweed, 2007).

Previous work in the study area was focused on the bedrock (Huber, 1948), especially for characterization of the NEAT Gotthard basis tunnel site below Sedrun (Schneider, 1992, and references therein). In the northern tributary valleys (Val Giuv, Val Mila, Val Strem; Fig. 2a) Aar granite dominates, while strongly sheared metamorphic rocks of the Tavetscher Zwischenmassif underlie the Vorderrhein Valley itself. Along the trough shoulder, especially at Cuolm da Vi (Fig. 2a), active deep-seated slope degradation is present as evidenced by abundant trenches and uphill facing scarps (Amann et al., 2006).

The aim of this study is to determine what caused this abrupt and apparently brief period of fan aggradation in the upper Vorderrhein. Previous researchers have interpreted the Sedrun and Disentis fans as kame terraces (Scapozza, 2012) or as Lateglacial outwash fans (Hantke, 1983). For the latter to be true the valley fill at Sedrun would have to be dominated by tributary valley sediment rather than Vorderrhein fluvial sediments. Both of these hypotheses require that the fans formed between about 17 and $11.7 \mathrm{kyr}$ ago.

\section{Methods}

To decipher the evolution of the upper Vorderrhein region and the origin of the Sedrun fans, we did detailed geomorphologic mapping supported by ArcGIS landscape analysis, as well as cosmogenic ${ }^{10} \mathrm{Be}$ exposure dating of boulders on moraines at the mouths of the three tributary valleys. No boulders suitable for exposure dating were found on any of the fan surfaces. Debris-flow sediments of the fans bury several of these moraines; thus the moraine dates pro- 


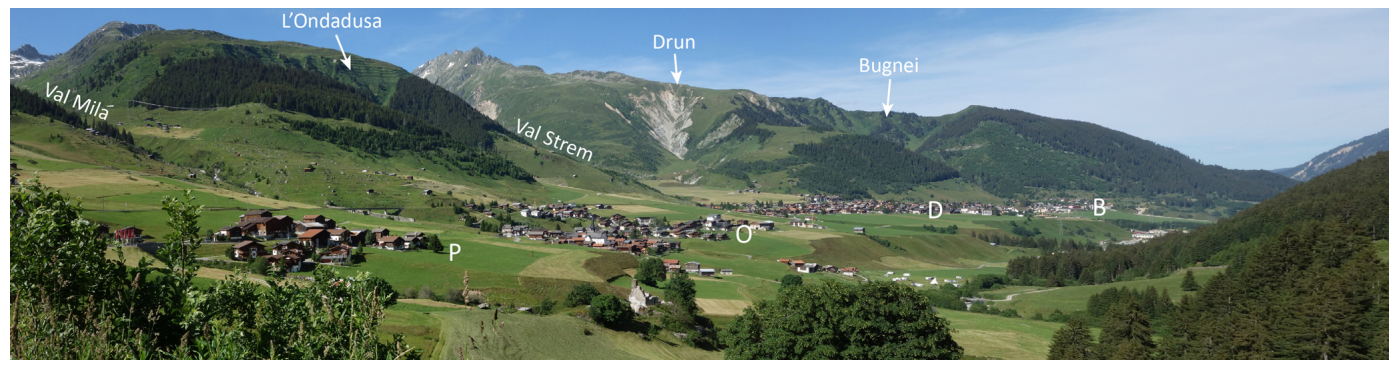

Figure 1. Panorama photograph (looking E) showing the coalesced-fan surface and the distinct cut-off toes of the fans in the upper Vorderrhein area near Sedrun. Fans and associated catchments are labelled P, Pulanera; O, L'Ondadusa; D, Drun; and B, Bugnei.
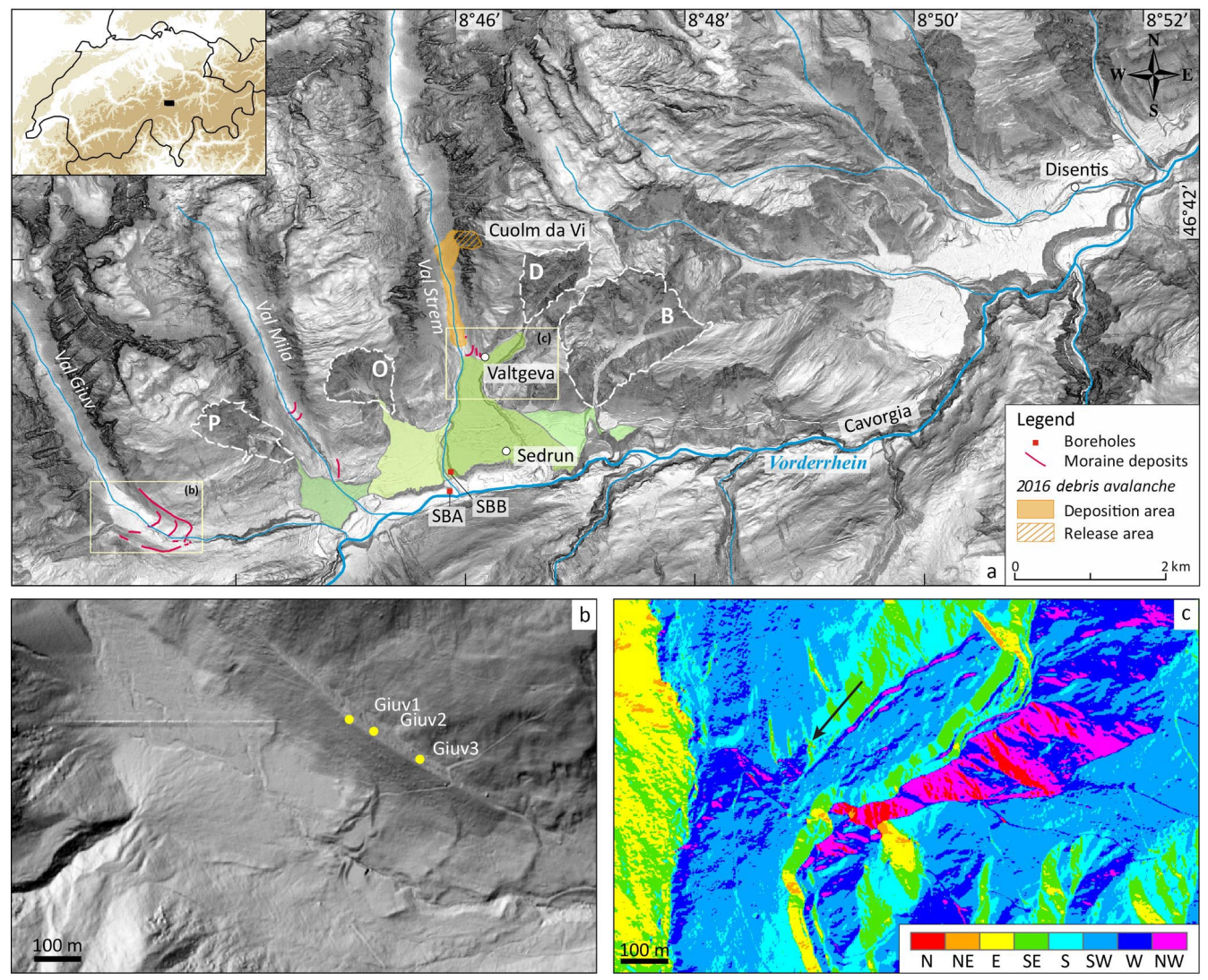

Figure 2. (a) Slope map based on $2 \pm 0.5 \mathrm{~m}$ resolution DEM (swissAlti3D, swisstopo JA100120) of the oversize fans near Sedrun and Disentis. Catchments (encircled with dashed line) connected to the Sedrun fans are labelled P, Pulanera; O, L'Ondadusa; D, Drun; and B, Bugnei. The 14 March 2016 debris avalanche release and deposit area are shown. Squares indicate locations of Fig. 2b and c. (b) Close-up of the moraines in Val Giuv with ${ }^{10}$ Be-dated boulder locations (dates shown in Fig. 4). (c) Close-up of the aspect map of the upper Drun fan. Note morphology of debris-flow levees on upper fan surface; arrow points to left-lateral moraines of the Val Strem paleoglacier that are partly buried by the upper Drun fan sediment.

vide maximum ages for aggradation of the fans. Sampling, sample preparation and age calculations for ${ }^{10} \mathrm{Be}$ exposure dating followed established procedures (Ivy-Ochs and Kober, 2008). Based on the mapped lateral and frontal moraines, paleoglaciers were reconstructed and the associated equilibrium line altitudes (ELAs) were calculated using the ArcGIS GlaRe tool (Pellitero et al., 2015, 2016). Knowledge of the ELA depression with respect to the Little Ice Age ELA is an- other means of estimating the timing of the glacier advance and associated moraine construction. We reconstructed the sedimentary fill of the upper Vorderrhein Valley based on our own outcrop descriptions combined with the information gleaned from the published NEAT core logs (Schneider, 1992). 

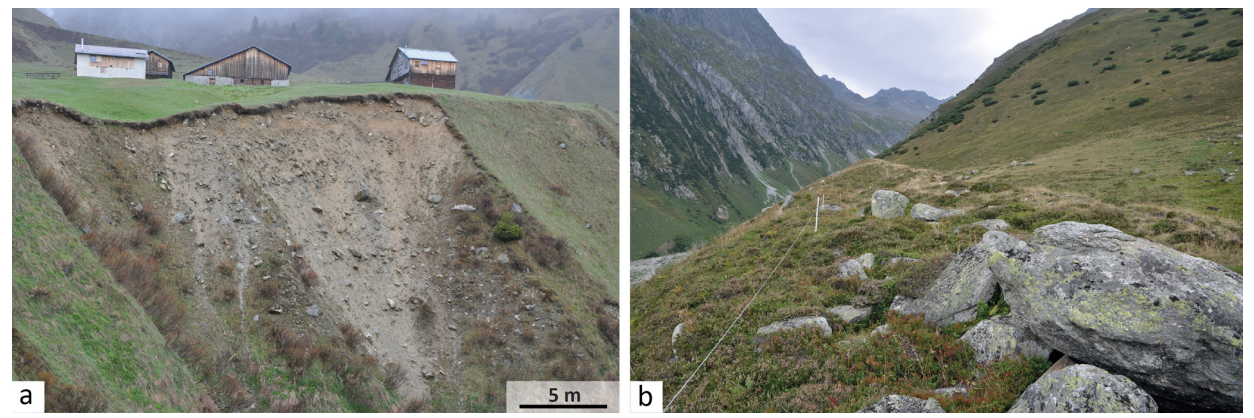

Figure 3. (a) Sediment of the upper Drun fan exposed in the Drun stream incision just south of Valtgeva (location shown in Fig. 2a). The outcrop is dominated by debris-flow deposits made up of crudely bedded, angular to subangular gneiss and schist cobbles and boulders (in part imbricated) in a silty, sandy matrix. Close to the top of the section, $\sim 0.75 \mathrm{~m}$ of interbedded laminated sands is visible, which is in turn overlain by another block layer. (b) View up into Val Giuv along the dated inner left-lateral moraine. Boulder Giuv1 is in the right foreground (age $10880 \pm 430$ years).

\section{Geomorphology of the upper Vorderrhein Valley}

\subsection{Fan morphology and valley fill}

The four fans studied here have a common, coalesced aggradation surface $(\sim 1380 \mathrm{~m}$ a.s.l.) that once must have extended all the way across the valley to the southern slope. Although the Pulanera fan is located at the mouth of Val Mila, the fan emanates from the small erosional-collapse catchment named Val Pulanera (Fig. 2a). At the toe of the Pulanera fan, incision by the Vorderrhein created a sequence of nine terraces. Riser height of the oldest terrace is $20 \mathrm{~m}$. The most recent terrace is $1 \mathrm{~m}$ above today's active channel. Just to the west at Val Giuv numerous lateral and frontal moraines mark past glacier positions (Fig. 2b), but there is very little outwash downstream of the moraines and no fan, and the Giuv stream enters a bedrock canyon before joining the Vorderrhein. The lower part of the canyon is filled with and draped by sediment of the neighbouring Pulanera fan. The L'Ondadusa fan is built up of material from the small catchment L'Ondadusa, which lies between Val Mila and Val Strem. Both the Pulanera and L'Ondadusa fans are largely inactive with little material being delivered to the fan today. Only tiny streams, which lack incised channels, traverse the two fans. The erosion escarpment along the Vorderrhein is about $50 \mathrm{~m}$ at L'Ondadusa and $70 \mathrm{~m}$ at the toe of the Drun fan. The Strem torrent, which separates the L'Ondadusa and Drun fans (Fig. 2a), has incised about $30 \mathrm{~m}$ into the topographically contiguous fan surface.

The Drun fan, which lies at the mouth of Val Strem, consists of a lower main fan and an upper fan to the northeast. Surface morphology shows that the fan itself does not emanate from Val Strem, but instead the upper fan sediment is sourced in the Drun catchment (Fig. 2c). The fan is a ski area and both the lower and upper fans were cleaned of large boulders. The upper Drun fan bears scattered boulders $(<0.5 \mathrm{~m}$ in height $)$ and faint levees of abandoned channels. Outcrops of the upper fan deposit along the incised Drun channel $(\sim 35 \mathrm{~m})$ near Valtgeva reveal several-metre-thick, matrix-supported block layers with infrequent interbedded laminated sands (Fig. 3a). The former are dominated by angular to subangular schist and gneiss blocks in a matrix of silty sand. The Drun catchment lies at the foot of the Cuolm da Vi, the site of active gravitational collapse and toppling with reported movement rates of some tens of centimetres per year (Amann et al., 2006). Several-metre-thick debris-flow deposits within the channel itself attest to recent deposition by the Drun torrent. Left lateral moraines present in Val Strem at Valtgeva are partially buried by the debris-flow sediments of the upper Drun fan (Fig. 2c). The most upvalley moraine was buried in part by the 14 March 2016 Val Strem debris avalanche (Fig. 2a). During this event the western flank of Cuolm da Vi collapsed and $\sim 200000 \mathrm{~m}^{3}$ of rock debris mixed with snow detached and ran up tens of metres on the opposite valley slope to eventually form a $\sim 1 \mathrm{~km}$ debris tongue (https://www.nzz.ch/panorama/ungluecksfaelle-undverbrechen/felssturz-in-sedrun-geroell-verschuettet-wasserund-stromversorgung-1.18712845, last access: 17 January 2018).

Two of the NEAT cores (Schneider, 1992) were taken close to the middle of the valley (locations shown in Fig. 2a). Examination of the published core log data allowed us a glimpse into the valley fill beneath the L'Ondadusa and Drun fans. Core SBA at $1342 \mathrm{~m}$ a.s.l. (2701381/1170326) lies in the Vorderrhein channel, while core SBB at $1358 \mathrm{~m}$ a.s.l. (2701314/1170165) lies in the Strem channel $\sim 240 \mathrm{~m}$ north of the Vorderrhein. Both cores traversed bedrock (Schneider, 1992), in SBA at $55 \mathrm{~m}$ depth (1288 ma.s.1.) and in SBB at $89 \mathrm{~m}$ depth (1269 ma.s.l.). This reach of the Vorderrhein Valley is overdeepened as shown by the top bedrock surface at $1269 \mathrm{~m}$ a.s.l. (core SBB), which is tens of metres lower than the bedrock threshold in the canyon near Bugnei at $1340 \mathrm{~m}$ a.s.l. The first $5-10 \mathrm{~m}$ of sediment on top of bedrock was interpreted by Schneider (1992) as sub- 
Table 1. Sample information, measured ${ }^{10} \mathrm{Be}$ concentrations and calculated surface exposure ages; all errors are $1 \sigma$.

\begin{tabular}{lrrrrrrr}
\hline $\begin{array}{l}\text { Sample } \\
\text { ID }\end{array}$ & Latitude & Longitude & $\begin{array}{r}\text { Elevation } \\
(\mathrm{m} \text { a.s.1. })\end{array}$ & $\begin{array}{r}\text { Sample } \\
\text { thickness }(\mathrm{cm})\end{array}$ & $\begin{array}{r}\text { Topographic } \\
\text { shielding factor }\end{array}$ & $\begin{array}{r}10 \text { Be concentration } \\
\left(10^{4} \mathrm{atg}^{-1}\right)^{\mathrm{a}}\end{array}$ & $\begin{array}{r}\text { Exposure } \\
\mathrm{age}^{\mathrm{b}}\end{array}$ \\
\hline Mila1 & 46.6835 & 8.7412 & 1672 & 2.0 & 0.966 & $15.36 \pm 0.67$ & $10120 \pm 440$ \\
Mila2 & 46.6782 & 8.7472 & 1532 & 2.3 & 0.985 & $18.64 \pm 0.93$ & $13430 \pm 670$ \\
Mila3 & 46.6790 & 8.7509 & 1512 & 2.4 & 0.987 & $18.62 \pm 0.79$ & $13600 \pm 580$ \\
\hline Giuv1 & 46.6741 & 8.7209 & 1841 & 4.0 & 0.979 & $18.64 \pm 0.73$ & $10880 \pm 430$ \\
Giuv2 & 46.6738 & 8.7213 & 1831 & 3.5 & 0.980 & $33.45 \pm 1.43$ & $19610 \pm 840$ \\
Giuv3 & 46.6734 & 8.7227 & 1795 & 2.5 & 0.982 & $20.31 \pm 0.76$ & $12070 \pm 450$ \\
\hline
\end{tabular}

a Analyses were normalized to the ETH AMS (accelerator mass spectrometry) standard S2007N (Christl et al., 2013). ${ }^{\mathrm{b}}$ Calculated with the online calculator of Balco et al. (2008) using the northeast North America calibration data set, a rock density of $2.65 \mathrm{~g} \mathrm{~cm}^{-3}$, and no erosion. Errors include the statistical uncertainties of the AMS measurement and the error on the subtracted blank $\left(3.5 \pm 2.5 \times 10^{-15}\right)$.

glacial till (overconsolidated diamicton). This is overlain by glaciofluvial gravels, rare interbedded glacigenic sediments ("tills") and lake sediments. The glaciofluvial deposits contain a broad spectrum of lithologies attesting to both local and Vorderrhein contributions. Starting at an elevation of about 1300 m a.s.l., Vorderrhein gravels with well-rounded clasts begin to dominate both cores. Schneider (1992) interpreted this as signalling the onset of the Holocene. No ${ }^{14} \mathrm{C}$ dates are reported for any of the NEAT cores in the valley. In core SBB, the presence of clean, well-sorted and at times crossbedded sands between elevations of 1330 and $1340 \mathrm{~m}$ a.s.l. was interpreted to indicate the presence of a lake (Schneider, 1992). Starting at elevation $1350 \mathrm{~m}$ a.s.l. and continuing to the top of core SBB poorly sorted, locally sourced debris-flow sediments with subangular gneiss blocks ranging up to $1 \mathrm{~m}^{3}$ in diameter were logged. The elevation of the (abandoned) Drun fan surface just adjacent to core SBB is at $1385-1390 \mathrm{~m}$ a.s.l., allowing $35-40 \mathrm{~m}$ of debris-flow sediments, which comprise the fan topography visible today.

Topographically, the abandoned Drun fan surface continues to the east to coalesce with the Bugnei fan, where the Vorderrhein has incised more than $120 \mathrm{~m}$ at the fan toe. Fan outcrops along the northern canyon wall indicate the presence of a pre-existing canyon that was filled by Bugnei debris. The canyon is contiguous with the Cavorgia bedrock canyon that separates the Sedrun fan surface from the Disentis fan surface (Fig. 2a). The rather uniform $7^{\circ}$ radial angle of the Bugnei fan surface on both the west and east side underscores the idea that during fan aggradation the (former) Cavorgia canyon must have been already completely filled up.

\subsection{Moraines and paleoglacier reconstruction}

Results of ${ }^{10} \mathrm{Be}$ exposure dating of moraine boulders are given in Table 1 and shown in Fig. 4. In Val Giuv, the prominent left-lateral moraine (Fig. 2b) is an accretionary moraine with the outermost left-lateral moraine (age $12070 \pm 450$ years, Giuv3) having been partially buried by the larger more prominent inner left-lateral moraine (age
$10880 \pm 430$ years, Giuv1, Fig. 3b). The apparently too old age of Giuv2 $19610 \pm 840$ years (also on outermost moraine) reflects cosmogenic nuclide inheritance and is not discussed further. Sub-parallel latero-frontal moraines at the mouth of Val Mila indicate that, $13430 \pm 670$ years ago (Mila2), the local glacier had just reached the main valley. The upvalley left-lateral moraine records stabilization of the glacier at a recessional position $10120 \pm 440$ years ago (Mila1). From a boulder on the left flank of the Vorderrhein Valley an age of $13600 \pm 580$ years (Mila3) was obtained. This gives a minimum age for the timing of an ice-free main valley. Pollen data indicate ice-free conditions around Sedrun by the beginning of the Bølling interstadial (ca. 14.6 kyr ago; Burga, 1987).

Comparison of the ELAs of the paleoglaciers provides an independent means of assessing contemporaneity of moraine formation in the three tributary valleys. Determined ELAs for the reconstructed paleoglaciers are 2300, 2230, and $2240 \mathrm{~m}$ a.s.l. (accumulation area ratio, AAR) for Val Giuv, Mila and Strem, respectively (Fig. 4). All three valleys hosted glaciers during the Little Ice Age. ELA depressions with respect to the Little Ice Age ELAs, which were 2700, 2570 and $2650 \mathrm{~m}$ a.s.l. (Maisch, 1992), are 400, 340 and $410 \mathrm{~m}$, respectively. ELA depression during the Egesen stadial across the Alps varies between 250 and $350 \mathrm{~m}$ (Ivy-Ochs, 2015, and references therein). Both the ${ }^{10} \mathrm{Be}$ ages and ELA depressions support the hypothesis that the studied moraines record advance of Val Giuv, Mila, and Strem glaciers during the Egesen stadial, which was between about 13 and $11.5 \mathrm{kyr}$ ago (Ivy-Ochs, 2015).

\section{Discussion and conclusions}

The dated left-lateral moraine at the mouth of Val Mila (Mila2) is buried along its downstream end by fan sediments sourced in the small basin Val Pulanera. In Val Strem three left-lateral moraines are partially buried by the Drun upper fan deposits (Fig. 2c). Although those moraines are undated, the similarity of the paleoglacier ELAs and $\triangle$ ELAs 


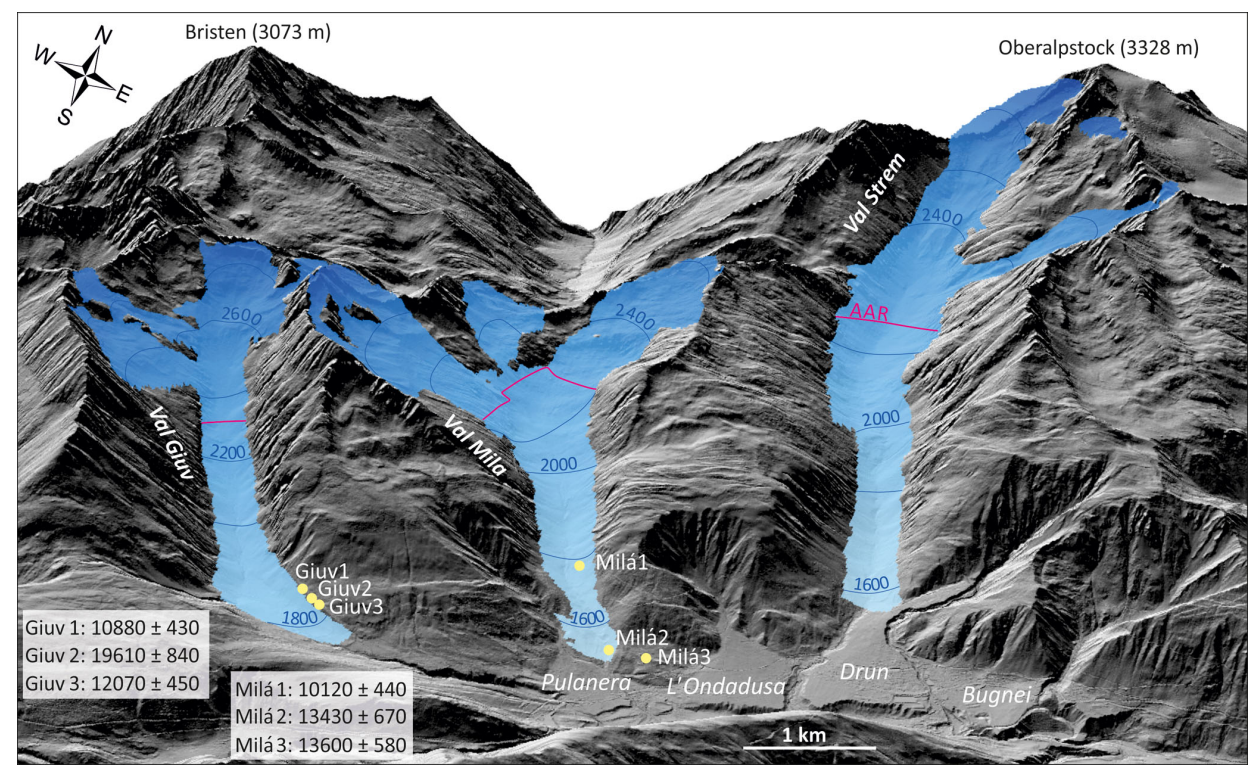

Figure 4. Reconstructed paleoglaciers in the three tributary valleys. Pink lines show the AAR ELAs calculated with the ArcGIS tool GlaRe (Pellitero et al., 2015, 2016). Yellow dots indicate the locations of ${ }^{10} \mathrm{Be}$-dated boulders. The corresponding ${ }^{10} \mathrm{Be}$ ages and their uncertainties are given. The coherence of the ELAs and $\triangle$ ELAs with respect to the Little Ice Age ELAs (see text) in concert with the ${ }^{10} \mathrm{Be}$ ages suggest that these glaciers advanced during the Alpine Lateglacial Egesen stadial.

with respect to Little Ice Age ELAs point to contemporaneity of moraine formation with the dated moraines in Val Giuv (12.9-10.9 kyr ago). As the footprint of the paleoglacier snout associated with the dated moraines (Fig. 4) was downstream of the Drun-Strem confluence, debris-flow activity post-dates the Egesen stadial. Similarly, the core data show that only the top 35-40 m of valley fill is actually debris-flow sediments; most is fluvial and glaciofluvial deposits of the Vorderrhein River, which accumulated in the overdeepening upstream of Bugnei. In sum, our data indicate that fan sediments built up after the end of the Lateglacial and that aggradation only took place for a few tens to at most hundreds of years (deposit thickness 30-40 m), when one considers that tens of metres of debris-flow sediment can accumulate in a single event (Harvey et al., 2005).

If the fans did not build up due to evacuation of Lateglacial glacial deposits from the tributary valleys, then why did they aggrade and why did aggradation stop and give way to toe incision so abruptly? We propose that the buildup of the Sedrun and Disentis fans was related to the damming of the Vorderrhein River by the Flims landslide. The Flims landslide (volume $9-12 \mathrm{~km}^{3}$ ) has been dated to 9400 cal yr BP with radiocarbon (Deplazes et al., 2007) and $8900 \pm 700$ years with cosmogenic ${ }^{10} \mathrm{Be}$ and ${ }^{36} \mathrm{Cl}$ (Ivy-Ochs et al., 2009). The Vorderrhein was completely blocked by a more than $600 \mathrm{~m}$-thick landslide dam and a lake, Ilanzersee, formed upstream (Wassmer et al., 2004; von Poschinger, 2005). This would have led to marked upstream aggradation for as long as the lake existed. Interestingly, in 1882 Heim mentioned that the Flims landslide-dammed lake had an im- pact on the landscape all the way up to Disentis, without giving details (Heim, 1882). The highest elevation of the lake is difficult to assess, especially as it may not have been at that elevation for very long. Wassmer et al. (2004) suggest a lake level of $1150 \mathrm{~m}$ a.s.l. but geomorphological evidence shows that a lake that high would have overflowed the landslide at numerous locations (cf. von Poschinger, 2005). It seems that the lake could have attained a level of around $940 \mathrm{~m}$ a.s.l. without overflowing (Fig. 5). Von Poschinger (2005) estimated a highest level of $936 \mathrm{~m}$ a.s.l. and a level that was held for fairly long at about $830 \mathrm{~m}$ a.s.l. As soon as the lake had filled with water (taking many years, disregarding seepage), a new higher local base level for all torrents upstream of the lake was established. The marked flattening of the river gradient and reduction in stream power led to immediate and rapid aggradation upstream. First to aggrade were the fans near Disentis whose fan toes were closest to the western end of the lake. At present, there is no evidence that the Disentis fans were deltas. As these fans grew they blocked the Cavorgia canyon (Fig. 2). Vorderrhein sediment choked the canyon and the Bugnei fan began to build up. This led to formation of accommodation space around Sedrun. As shown by the core data, first a lake formed west of Bugnei (recorded by sand layers between 1330 and $1340 \mathrm{~m}$ a.s.l. in core SBB), then the three fans, Pulanera, L'Ondadusa and Drun, aggraded and coalesced to form a continuous surface with an elevation of about $1380 \mathrm{~m}$ a.s.l. Ilanzersee never filled completely with sediment but emptied (likely stepwise) due to breaches in the landslide deposit where the present Vorderrhein channel is. The uniformity of the marked cut-off toes of the Disentis and 


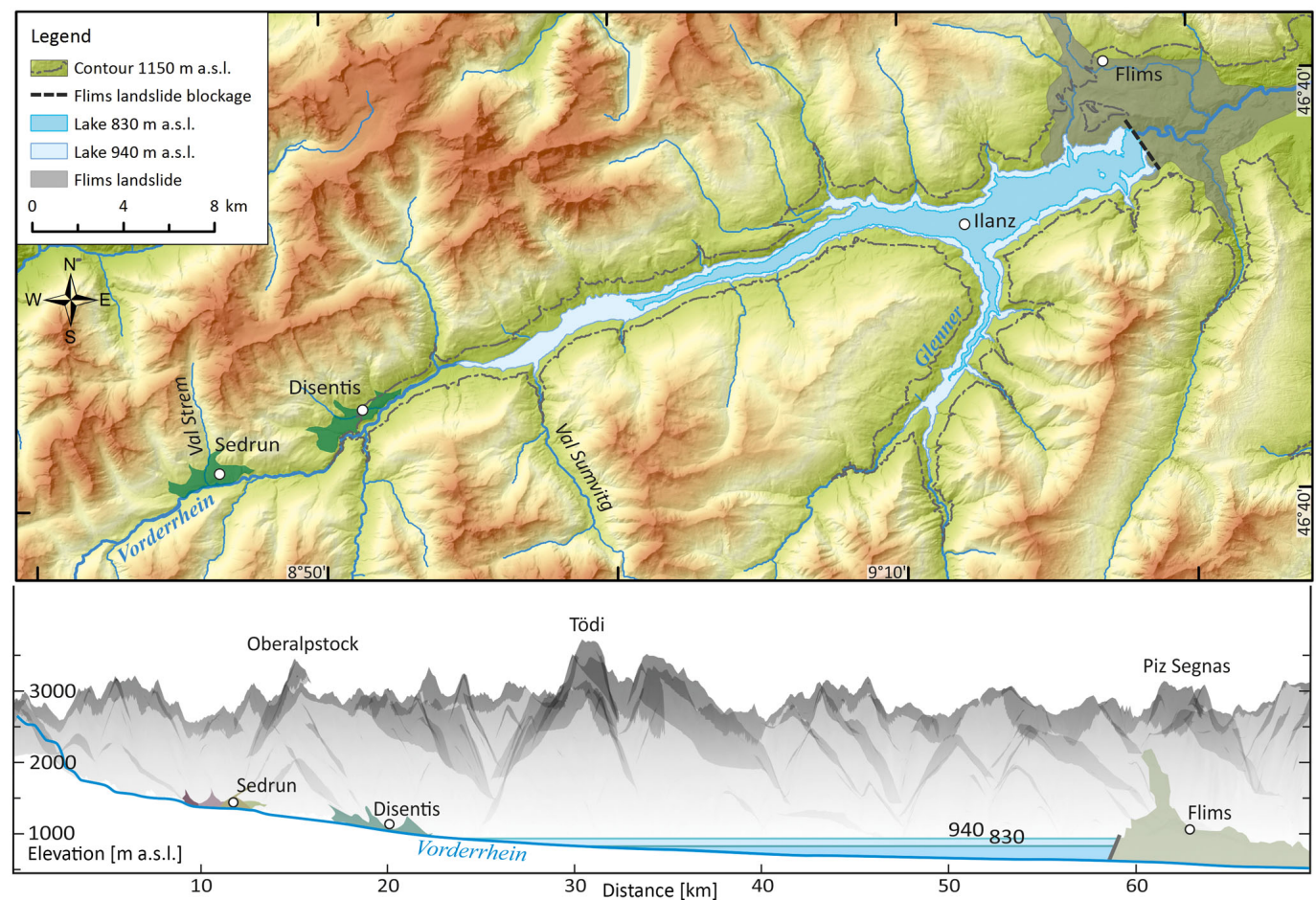

Figure 5. Coloured elevation overlain on hillshade map of the area between Disentis and Flims (swisstopo JA100120). The dark grey area represents the Flims landslide deposits. The black thick dashed line indicates the location of the blockage of the Vorderrhein River by the landslide dam (von Poschinger, 2005). The proposed Ilanzersee shoreline at an elevation of $1150 \mathrm{~m}$ a.s.l. (Wassmer et al., 2004) is outlined in grey dots. This reconstruction shows that a lake with surface at $1150 \mathrm{~m}$ a.s.l would have overflowed the landslide dam at several points both north and south of the location of the blockage and subsequent final breach. The white and light blue areas show extents of Ilanzersee with shorelines of 940 and 830 m a.s.l., respectively, as proposed by von Poschinger (2005). Lower panel: longitudinal ESE-WNW profile along the Vorderrhein River down to the Flims landslide deposits. The two lake levels, 940 and $830 \mathrm{~m}$ a.s.l., are shown. In the background the mountain peaks to the north are illustrated. Vertical exaggeration $2.5 \times$.

Sedrun fans suggests coherent response to an abrupt downstream change in base level, which we suggest was the draining of Ilanzersee. As the lake level decreased suddenly, the Vorderrhein was able to clear out the Cavorgia canyon (there is no evidence for formation of a new bedrock canyon epigenetically), base level dropped and fan aggradation ceased. The fan toes were incised. The associated knickpoint is now located near the outlet of the Drun torrent just west of the Bugnei fan, as attested by the bedrock outcrops in the channel at elevation $1340 \mathrm{~m}$ a.s.l. This is also the approximate elevation of the present floodplain upstream of this point. The broad floodplain ( $200 \mathrm{~m}$ wide) and the nine cut terraces reflect meandering of the Vorderrhein near Pulanera and point to the river being in a stable state at present along this reach.

Data availability. All primary data for this paper are given in the tables. Data are archived in the expage database (http://expage. github.io/, last access: 17 April 2018).
Competing interests. The authors declare that they have no conflict of interest.

Acknowledgements. AlpTransit Gotthard AG and swisstopo are thanked for allowing access to drill core data for the Gotthard basis tunnel site. We are grateful for support of fieldwork, sample preparation and AMS measurements provided by the Ion Beam Physics group at ETH Zurich. Constructive reviews and comments by an anonymous reviewer and Christopher Lüthgens helped us to improve the manuscript.

\section{References}

Amann, F., Donatsch, G., Bonanomi, Y., and Moser, M.: Kinematik und Bewegungsmechanismus der tiefgründigen Instabilität Cuolm Da Vi (Graubünden, Schweiz), Bulletin für angewandte Geologie, 11, 117-131, 2006.

Balco, G., Stone, J. O., Lifton, N. A., and Dunai, T. J.: A complete and easily accessible means of calculating surface exposure ages or erosion rates from ${ }^{10} \mathrm{Be}$ and 
${ }^{26} \mathrm{Al}$ measurements, Quaternary Geochronology, 3, 174-195, https://doi.org/10.1016/j.quageo.2007.12.001, 2008.

Burga, C. A.: Das alpine Spät- und Postglazial in Graubünden aufgrund geomorphologischer und pollenanalytischer Untersuchungen, Vierteljahresschrift der Naturforschenden Gesellschaft in Zürich, 132, 26-44, 1987.

Christl, M., Vockenhuber, C., Kubik, P. W., Wacker, L., Lachner, J., Alfimov, V., and Synal, H.-A.: The ETH Zurich AMS facilities: Performance parameters and reference materials, Nucl. Instrum. Meth. B, 294, 29-38, https://doi.org/10.1016/j.nimb.2012.03.004, 2013.

Deplazes, G., Anselmetti, F. S., and Hajdas, I.: Lake sediments deposited on the Flims rockslide mass: the key to date the largest mass movement of the Alps, Terra Nova, 19, 252-258, https://doi.org/10.1111/j.1365-3121.2007.00743.x, 2007.

Hantke, R.: Eiszeitalter: Die jüngste Erdgeschichte der Alpen und ihrer Nachbargebiete, Ott, Thun, Switzerland, 1983.

Harvey, A. M. Mather, A. E., and Stokes, M.: Alluvial Fans: Geomorphology, Sedimentology, Dynamics Geological Society, London, UK, Special Publications, 251, 248 pp., https://doi.org/10.1144/GSL.SP.2005.251.01.16, 2005.

Heim, A.: Der alte Bergsturz von Flims, Jahrbuch des Schweizer Alpenclub, Bern, Switzerland, 18, 295-309, 1882.

Hornung, J., Pflanz, D., Hechler, A., Beer, A., Hinderer, M., Maisch, M., and Bieg, U.: 3-D architecture, depositional patterns and climate triggered sediment fluxes of an alpine alluvial fan (Samedan, Switzerland), Geomorphology, 115, 202-214, https://doi.org/10.1016/j.geomorph.2009.09.001, 2010.

Huber, W.: Petrographisch-mineralogische Untersuchungen im südöstlichen Aarmassiv, Schweiz. Miner. Petrog., 2, 557-642, 1948.

Ivy-Ochs, S.: Glacier variations in the European Alps at the end of the last glaciation, Cuadernos de investigación geográfica, 41, 295-315, https://doi.org/10.18172/cig.2750, 2015.

Ivy-Ochs, S. and Kober, F.: Surface exposure dating with cosmogenic nuclides, E\&G Quaternary Sci. J., 57, 179-209, https://doi.org/10.3285/eg.57.1-2.7, 2008.
Ivy-Ochs, S., Poschinger, A. V., Synal, H. A., and Maisch, M.: Surface exposure dating of the Flims landslide, Graubünden, Switzerland, Geomorphology, 103, 104-112, https://doi.org/10.1016/j.geomorph.2007.10.024, 2009.

Korup, O. and Tweed, F.: Ice, moraine, and landslide dams in mountainous terrain, Quaternary Sci. Rev., 26, 3406-3422, https://doi.org/10.1016/j.quascirev.2007.10.012, 2007.

Maisch, M.: Die Gletscher Graubündens, Part B, Geographisches Institut Universität Zürich, Zürich, Switzerland, 1992.

Pellitero, R., Rea, B. R., Spagnolo, M., Bakke, J., Hughes, P., Ivy-Ochs, S., Lukas, S., and Ribolini, A.: A GIS tool for automatic calculation of glacier equilibrium-line altitudes, Comput. Geosci., 82, 55-62, https://doi.org/10.1016/j.cageo.2015.05.005, 2015.

Pellitero, R., Rea, B. R., Spagnolo, M., Bakke, J., IvyOchs, S., Frew, C. R., Hughes, P., Ribolini, A., Lukas, S., and Renssen, H.: GlaRe, a GIS tool to reconstruct the 3D surface of palaeoglaciers, Comput. Geosci., 94, 77-85, https://doi.org/10.1016/j.cageo.2016.06.008, 2016.

Scapozza, C.: Kame Terrassen Camischolas (Disentis, Sedrun, GR), Géotope Suisse, no. 284 (GR), Bern, Switzerland, 2012.

Schneider, T.: Geologische Auswertung (Schlussbericht) Sondierbohrungen Tujetsch, NNE Rueras, Bundesamt für Verkehr und AlpTransit, Bern, Switzerland, 1992.

Von Poschinger, A.: Der Flimser Bergsturz als Staudamm, Bulletin für angewandte Geologie, 10, 33-47, https://doi.org/10.5169/seals-225564, 2005.

Wassmer, P., Schneider, J. L., Pollet, N., and Schmitter-Voirin, C.: Effects of the internal structure of a rock-avalanche dam on the drainage mechanism of its impoundment, Flims sturzstrom and Ilanz paleo-lake, Swiss Alps, Geomorphology, 61, 3-17, https://doi.org/10.1016/j.geomorph.2003.11.003, 2004. 